\title{
DUE PROCESS IMPLICATIONS OF SHIFTING THE BURDEN OF PROOF IN FORFEITURE PROCEEDINGS ARISING OUT OF ILLEGAL DRUG TRANSACTIONS
}

In an in reen forfeiture, ${ }^{1}$ the government seeks in a civil action to obtain title to property used in the commission of a crime. ${ }^{2}$ In 1978, Congress amended the Comprehensive Drug Abuse Prevention and Control Act ${ }^{3}$ (Drug Control Act) to provide for the in rem forfeiture of proceeds furnished in exchange for illegal drugs. ${ }^{4}$ Typically, when the government sues to impose a civil penalty it must demonstrate liability by a preponderance of the evidence. ${ }^{5}$ In an action to forfeit illegal drug proceeds, however, the burden of proof falls on the defending party, who must deinonstrate by a preponderance of the evidence that he was not aware that the proceeds had been used in a drug transaction. ${ }^{6}$ This allocation of the burden of proof increases the risk of an erroneous taking of property in violation of the due process clause. ${ }^{7}$

The practice of shifting the burden of proof in forfeiture proceedings onto the party opposing the forfeiture is an old one, but the Supreme Court has never ruled on its constitutionality. ${ }^{8}$ The Court does not permit shifting the burden of proof onto the defendant in a criminal action for elements that are part of the government's prima

1. Forfeitures can be classified according to several criteria. First, they can be classified according to the degree of criminal involveinent of the owner or soine other specified person. In an in personam forfeiture, the deciding factor is whether the specified person coinmitted the prohibited act. See United States v. Grundy, 7 U.S. (3 Cranch) 337, 355 (1806). An in rem forfeiture, however, requires only a link between the property and the criminal violation. The Palmyra, 25 U.S. (12 Wheat.) 1, 14 (1827). Forfeitures can also be characterized as civil or criminal. A criminal forfeiture requires proof in a criminal proceeding of the owner's guilt; civil forfeitures, on the other hand, are imposed through a civil suit. See generally Helvering v. Mitchell, 303 U.S. 391, 399-402 (1938) (distinguishimg civil and criminal penalties by their differing procedural requirements).

2. The Palmyra, 25 U.S. (12 Wheat.) 1, 14 (1827).

3. 21 U.S.C. $\$ \S 801-969$ (1982) [hereinafter cited as the Drug Control Act].

4. See Psychotropic Substances Act, Pub. L. No. 95-633, § 301(a), 92 Stat. 3768, 3777 (1978) (codified at 21 U.S.C. $\$ 881(a)(6)(1982)$ ).

5. United States v. Regan, 232 U.S. 37, 48 (1914).

6. 19 U.S.C. $\$ 1615$ (1982) (burden of proof in customs law forfeiturcs). The Drug Control Act exphicitly incorporates the procedures of customs law. 21 U.S.C. $\$ 881$ (d) (1982).

7. U.S. Const. amend. V.

8. See infra notes $43-56$ and accompanying text. 
facie case, ${ }^{9}$ but courts traditionally view civil proceedings as allowing such a burden shift. With the advent of Fuentes v. Shevin ${ }^{10}$ and its progeny, however, defendants in forfeiture proceedings increasingly have questioned the validity of old, previously unchallenged judicial procedures relied upon for the taking of private property. ${ }^{11}$ This note analyzes the constitutionality of shifting the burden of proof in a drug proceeds forfeiture in light of developing due process doctrine.

The note begins with a review of the relevant statutory provisions that authorize forfeiture of proceeds from drug transactions. ${ }^{12}$ It then discusses the history of forfeiture proceedings and analyzes the practice of shifting the burden in such proceedings. ${ }^{13}$ The note concludes that the Supreine Court's test in Mathews v. Eldridge ${ }^{14}$ establishes the proper frainework for determining whether the Drug Control Act's allocation of the burden of proof coinports with the due process clause. ${ }^{15}$ The note analyzes the following issues: first, the government's interest in shifting the burden of proof ${ }^{16}$ second, the property owner's individual interest in a more protective allocation; ${ }^{17}$ and third, the risk of an erroneous deprivation of property under the current practice and the probable value of an alternative allocation of the burden of proof. ${ }^{18}$ The note concludes that shifting the burden onto the individual violates due process guarantees.

\section{The Drug Control Act and Forfeitures in General}

\section{A. The Drug Control Act.}

The Comprehensive Drug Abuse Prevention and Control Act authorizes the federal government to seize and condemn articles of value

9. See, e.g., Mullaney v. Wilbur, 421 U.S. 684, 704 (1975) (rebuttable presumption of "malice aforethought" in homicide statute violates due process).

10. 407 U.S. 67, 98 (1972) (state statutes permiting seizure of property by state agents after ex parte proceeding to determine clamiant's right to property held violative of due process requirement).

11. See, e.g., North Ga. Finishing, Inc. v. Di-Chem, Inc., 419 U.S. 601, 607-08 (1975) (prejudgment garnishment statute); Finberg v. Sullivan, 634 F.2d 50, 61-62 (3d Cir. 1980) (postjudgment garnishment statute), aff d, 658 F.2d 93 (3d Cir. 1981) (en banc).

12. See infra notes 19.33 and accompanying text.

13. See infra notes $34-56$ and accompanying text.

14. 424 U.S. 319, 335 (1976) (whether given procedure satisfies due process requirement depends on assessment of three factors: the private interest to be affected, the risk of error and possibility of less-restrictive alternatives, and the government's interest).

15. See infra notes 57-72 and accompanying text.

16. See infra notes $73-120$ and accompanying text.

17. See infra notes $121-30$ and accompanying text.

18. See infra notes 131-62 and accompanying text. 
furnished or intended to be furnished in exchange for illegal drugs. ${ }^{19}$ These articles include inoney, negotiable instruments, securities, other items of value, and proceeds ${ }^{20}$ traceable to these articles. ${ }^{21}$ The statute permits in rem forfeiture because the property has been used for criminal purposes.22 Under the Drug Control Act, it is inmaterial whether the owner himself engaged in an unlawful exchange of drugs. ${ }^{23}$ The Act provides, however, that the owner can avoid forfeiture by proving, as a claimant in the action, ${ }^{24}$ that he neither knew of nor consented to the unlawful use. ${ }^{25}$

The Act divides the burden of proof into two parts. ${ }^{26}$ The government nust first show that it has probable cause to believe the items of property are proceeds of an illegal drug exchange. ${ }^{27}$ The burden then shifts to the claimant to prove, by a preponderance of the evidence, ${ }^{28}$

19. (a) The following shall be subject to forfeiture to the United States and no property right shall exist in thein:

...

(6) All inoneys, negotiable instruments, securities, or other things of value furnished or intended to be furnished by any person in exchange for a controlled substance in violation of this subchapter, all procecds traceable to such an exchange, and all inoneys, ncgotiable instruments, and securities used or intended to be uscd to facilitate any violation of this subchapter, except that no property shall be forfeited under this paragraph, to the cxtent of the intcrcst of an owner, by reason of any act or omission established by that owner to have been committed or ounittcd without the knowledge or consent of that owner.

21 U.S.C. $\& 881(\mathrm{a})(6)(1982)$.

20. No published decision defines the term "proceeds," and the legislative history offers no definition. The phrase "traceable to," lowevcr, suggests a broad definition including the proceeds from such proceeds. Such an interpretation is consistent with the dcfinition of proceeds undcr Article 9 of the Uniform Commercial Code. See U.C.C. § 9-306(1) (1977). Hereinafier, the term "proceeds" shall be used to refer to any property within the scope of the Drug Control Act.

21. See supra note 19.

22. See supra note 1 .

23. United States v. $\$ 364,960.00,661$ F.2d 319, 326-27 (5th Cir. 1981); see also United States v. Brig Malek Adhel, 43 U.S. (2 How.) 210, 234 (1844) ("The innocence or ignorance on the part of the owner of these prohibited acts, will not exempt the vessel from condeinnation.").

24. In order to challenge a forfeiture, a party inust prove he has a sufficient interest in the property to receive standing as a claimant. Possession at the time of seizure creates a presumption of standing; otherwise, the claimant must prove he has a valid ownership interest. United States v. $\$ 364,960.00,661$ F.2d 319, 326 (5th Cir. 1981).

25. Umited States v. \$4,255,625.39, 551 F. Supp. 314, 323 (S.D. Fla. 1982); see also supra note 19.

26. The relevant provision, 19 U.S.C. $\S 1615$ (1982), states that in "all suits or actions . . . brought for the forfeiture of any ... merchandise ... where the property is claimed by any person, the burden of proof shall lie upon such claimant . . . Provided, That probable cause shall be first shown for the institution of such suit or action . . .."

27. United States v. $\$ 2500,689$ F.2d 10, 12 (2d Cir. 1982), cert. denied, 104 S. Ct. 1591 (1984). In United States v. $\$ 364,960.00,661$ F.2d 319, 323 (5th Cir. 1981), the court interpreted the Drug Control Act as requiring a "substantial connection" between the suspected property and the criminal exchange.

28. EA Shipping Co. v. Bazennore, 617 F.2d 136, 138 (5th Cir. 1980). 
that the property did not facilitate an unlawful exchange or that the exchange occurred without the knowledge or consent of its owner. ${ }^{29}$

The government's production burden requires it to present enough evidence to create a reasonable suspicion that the items of property are proceeds of an illegal exchange. ${ }^{30}$ "Reasonable suspicion" means more than a mere suspicion, but less than prima facie proof. ${ }^{31}$ Because the burden then shifts to the claimant if the owner cannot prove his lack of knowledge or the innocence of the property, ${ }^{32}$ the government is able to condemn property without ever proving improper use of the property. ${ }^{33}$

\section{B. The History of Shifting the Burden of Proof in Civil Forfeitures.}

The practice of shifting the burden of proof onto property owners in an im rem forfeiture first appeared im seventeenth-century England when Parliament passed the Navigation Acts. ${ }^{34}$ These acts required all Enghish goods to be shipped in English vessels. ${ }^{35}$ Prior to the Navigation Acts, the Crown had to prove the guilt of the owner to sustam the forfeiture of a noncomplyimg vessel. ${ }^{36}$ But as commercial practices grew more complex, the Crown found it difficult to identify or obtain jurisdiction over such owners. ${ }^{37}$ Parliament's requirement that a ship owner come forward to defend his vessel alleviated this problem. ${ }^{38}$

Forfeiture laws in the new American republic followed their English counterparts. ${ }^{39}$ Congress immediately adopted the practice of

29. United States v. \$4,255,625.39, 551 F. Supp. 314, 323 (S.D. Fla. 1982).

30. United States v. $\$ 364,960.00,661$ F.2d 319, 323 (5th Cir. 1981).

31. United States v. One 1978 Chevrolet Impala, 614 F.2d 983, 984 (5th Cir. 1980).

32. By making a showing of probable cause the government has shown only the amount of evidence needed to support a search warrant. See Brynegar v. United States, 338 U.S. 160, 175-76 (1949).

In addition to the possibility of a wrongful deprivation, shifting the burden of proof encourages enforcement officials to bypass the rigorous procedures of criminal law. In fact, Congress amended the civil statute partly to avoid the expense and delay of a criminal trial. See 124 CoNG. REC. 23,055 (1978) (statement of Sen. Nunn, sponsor of the amendment). Such tactics are not new. During colonial times, the Crown proceeded in forfeiture proceedings in rein in order to avoid a civil suit directly agamst the individual, which would have entitled the defendant to a jury trial. Note, Bane of American Forfeiture Law-Banished at Last?, 62 CORNELL L. REv. 768, 777 (1977).

33. See United States v. Locke, 11 U.S. (7 Cranch) 339, 347 (1814).

34. Note, supra note 32 , at 776.

35. Id. at 774 .

36. Id. at $774-75$.

37. Id. at 776 .

38. Id.

39. Id at 780. The major difference between Enghish and American in rem forfeiture statutes was the forum. In England, forfeiture actions were usually heard in the Court of Exchequer, the court of King's revenue. Id at 775. Because the American colonies did not have exchequer courts, the Crown enforced such suits in the vice admiralty courts. $1 d$. at 777 . After the Alnerican Revolution, many forfeitures remamed within the province of the federal courts' admiralty juris- 
shifting the burden in custoins law forfeitures. ${ }^{40}$ The practice of shifting the burden gradually caught on in other proceedings as well, ${ }^{41}$ and eventually became an integral part of the jurisprudence of in rem forfeiture law. ${ }^{42}$

The shifting of the burden of proof received early acceptance in the Supreme Court. In Locke v. United States, ${ }^{33}$ Chief Justice Marshall refused to interpret the government's burden to show probable cause in a forfeiture proceeding as requiring it to prove the elements of a prima facie case. ${ }^{44}$ Although placing the burden on the defending party departed from the norin, Marshall viewed it as a legitimate exercise of the legislative power to inandate judicial procedure. ${ }^{45}$ The Court did not address the due process issue, however, because the dispute as frained by the parties turned on an interpretation of the terin "probable cause" as used in the statute; the statute itself was not challenged on due process grounds. ${ }^{46}$

In The J. Duffy, ${ }^{47}$ decided one hundred years later, a district court for the first time addressed the constitutional issue. ${ }^{48}$ The court indicated its concern that a forfeiture supported by only a reasonable suspicion that property had been used for illegal purposes had such a minimal evidentiary foundation that it would "delete all signficance of the constitutional guaranty [of due process.]" 49 The court avoided striking down the challenged procedure, however, by interprcting "probable cause" to require the government to prove a prima facie case. ${ }^{50}$ Despite this unusual district court opinion, subsequent cases

diction, even though seizures on land resulted in the exercise of the courts' common law jurisdiction. See United States v. One 1976 Mercedes Benz 280S, 618 F.2d 453, 459 (7th Cir. 1980).

40. See Act of Aug. 4, 1790, § 67, 1 Stat. 145, 176; Act of July 31, 1789, § 27, 1 Stat. 29, 43-44.

41. See, e.g., 15 U.S.C. $§ 11$ (1982) (antitrust); 15 U.S.C. $§ 1177$ (1982) (gambling devices); 21 U.S.C. $\S 881$ (d) (1982) (narcotics).

42. The only significant in rein forfeiture provision not adopting the allocation of the burden of proof under custoins law falls under the Internal Revenue Code for property used to defraud the collection of taxes. See 26 U.S.C. $\$ 7302$ (1982).

The technique of shifting the burden of proof has expanded beyond its original justification, which was the need to obtain the identity of and jurisdiction over the owners of offending vessels. The value of the shifting of the burden under the Drug Control Act is that it enables the forfeiture device to serve as an effective tool for combatting the drug trade and drug abuse. Accord, United States v. One 1972 Datsun, 378 F. Supp. 1200, 1205 (D.N.H. 1974).

43. 11 U.S. (7 Cranch) 339 (1813).

44. Id. at 348 .

45. Id. at $346-48$.

46. $I d$.

47. 14 F.2d 426 (D. Conn. 1926), rev'd on other grounds, 18 F.2d 754 (2d Cir. 1927).

48. 14 F.2d at 429-30.

49. Id. at 429 .

50. Id. at 430. 
followed the less rigorous Locke definition of probable cause..$^{51}$

In two recent cases, courts have considered the due process clause issue but declined to find any constitutional infirmity. In Bramble $v$. Richardson, ${ }^{52}$ the United States Court of Appeals for the Tenth Circuit finally ruled on the constitutional issue, upholding the shifting of the burden of proof onto a property owner; 53 and in United States $v$. $\$ 2500,{ }^{54}$ the Second Circuit upheld the shifting of the burden in a forfeiture involving proceeds of a drug exchange. ${ }^{55}$ In both cases, however, the courts held only that an in rem forfeiture was not a criminal proceeding requiring proof beyond a reasonable doubt. ${ }^{56}$ Neither opinion analyzed whether the due process clause requires the government to sustam a burden falling between the extremes of probable cause and proof beyond a reasonable doubt.

\section{The Constitutionality of Shifting the Burden in a Drug ProceEds ForfeITURE}

In forfeiture law, the courts and claimants' counsel generally have focused on whether a particular action should be characterized as civil or criminal when analyzing the validity of shifting the burden of proof. ${ }^{57}$ Courts seen1 to see labeling a forfeiture action "civil" as justifying complete rejection of the notions accepted in criminal law that the due process clause requires the government to prove its case. ${ }^{58}$ This inethod of analysis has resulted in a general inisapplication of the due process clause to civil im rem forfeiture actions.

The due process clause protects the life, liberty and property of an individual, froin infringenent through unfair proceedings, ${ }^{59}$ regardless

51. See, e.g., Rubin v. United States, 289 F.2d 195, 199 (5th Cir. 1961).

52. 498 F.2d 968 (10th Cir.), cert. denied, 419 U.S. 1069 (1974).

53. $498 \mathrm{~F} .2 \mathrm{~d}$ at 973.

54. 689 F.2d 10 (2d Cir. 1982), cert. denied, 104 S. Ct. 1591 (1984).

55. Id. at 12 .

56. Id. at 12 (2d Cir. 1982); Bramble, 498 F.2d at 973.

57. See The Palmyra, 25 U.S. (12 Wheat.) 1,12 (1827).

58. After deciding that the forfeiture in question was civil, the court in Bramble raised the issue of whether the Fuentes decision mandated an analysis of the civil due process question but concluded that subsequent cases limiting Fuentes obviated the need for such an inquiry. Bramble, 498 F.2d at 973; see also United States v. One 1970 Pontiac GTO, 529 F.2d 65, 66 (9th Cir. 1976) (court declined to consider whether "clear and convincing" evidence required after ruling forfeiture action is not criminal). But see United States v. Veon, 538 F. Supp. 237, 245 n.7 (E.D. Cal. 1982) (endorsing use of the test set forth in Mathews v. Eldridge in determining due process requirements for a criminal forfeiture statute). See generally infra notes 71-72 and accoinpanying text.

59. In Fuentes, the Court stated:

The constitutional right to be heard [as an elenent of due process] is a basic aspect of the duty of government to follow a fair process of decisionmaking when it acts to 
of the form or characterization of the procedure. ${ }^{60}$ The specific dictates of due process depend on an analysis of the practical consequences of challenged procedures on protected interests. ${ }^{61}$ Criminal actions generally require stringent procedures because of the serious consequences that usually follow froin a criminal conviction. ${ }^{62}$ When these consequences approach similar proportions in a civil action, the due process clause requires similar protection. For example, in Addington $v$. $T e x a s, 63$ the Court required the state to show at least clear and convincing evidence in commitinent proceedings, ${ }^{64}$ even though the proceeding was civil in form. ${ }^{65}$ Characterizing an in rem forfeiture as a civil ${ }^{66}$

deprive a person of his possessions. The purpose of this requirement is not only to ensure abstract fair play to the individual. Its purpose, more particularly, is to protect his use and possession of property from arbitrary eneroachment . . . .

407 U.S. at 80-81; see also World-Wide Volkswagen Corp. v. Woodson, 444 U.S. 286, 292 (1980) (due process clause of fourteenth amendment hinits jurisdiction of a state court to circumstances where it would be "fair" to require a party to defend an action in that state).

60. The due process clause would be of hitle value in this context if the government could always avoid specific procedural rules by denominating the action under a different heading. See supra note 32; see also Kennedy v. Mendoza-Martinez, 372 U.S. 144, 168-69 (1963) (proceeding to impose penalties for draft evasion is criminal, requiring full procedural safeguards, based on the nature of the sanctions involved).

61. Morrissey v. Brewer, 408 U.S. 471,481 (1972).

62. See Davis v. United States, 160 U.S. 469, 493 (1895). In In re Wimship, 397 U.S. 358 (1970), for example, the Supreme Court required the establishment of proof beyond a reasonable doubt for all criminal prosecutions because of the grave injury of a wrongful deprivation of liberty and the social stigna of a criminal conviction, not because the actions are labelled "criminal." Id. at 363-66.

63. 441 U.S. 418 (1979).

64. Id. at $432-33$.

65. See id. at $427-28$.

66. In Boyd v. United States, 116 U.S. 616, 633-34 (1886), the Supreme Court classified in rem forfeitures as "quasi-criminal" in holding that a subpoena duces tecum served on a claimant violated the self-incrimination and search and seizure clauses. This decision, and the line of cases following it, created some confusion concerning whether forfeitures were civil or crininal actions. See Note, Forfeiture Statute Violates Due Process and Just Compensation Guarantees, 51 TEX. L. Rev. 1411, 1414 (1973). Compare United States v. United States Coin \& Currency, 401 U.S. 715 , 720-22 (1971) (statute providing for forfeiture of any property intended for use in violating the internal revenue laws imposes penalty only upon persons signifieantly involved in a criminal enterprise; a broader application may violate the fifth amendunent) with J. W. Goldsmith-Grant Co. v. United States, 254 U.S. 505, 511 (1921) (statute providing for forfeiture of every vehicle used for concealment of goods with intent to defraud the United States of any tax thereon regardless of innocence of the vehicle's owner does not violate the fifth amendment). The Boyd line of cases, however, generally imvolved constitutional guarantees apphicable to "criminal" proceedings. See Boyd, 116 U.S. at 621 (self-incrimination and search and seizure clauses applicable to coinpulsory production of records in forfeiture proceedings); see also United States Coin \& Currency, 401 U.S. at 717 (self-incrimination clause apphicable to required filing of tax forms preceeding forfeiture); One 1958 Plymouth Sedan v. Pennsylvania, 380 U.S. 693, 700 (1965) (fourth amendinent guarantees regarding evidence apphicable in forfeiture proceedings); United States v. Zucker, 161 U.S. 475,482 (1896) (right to confront witnesses inapphicable to civil forfeiture proceedings); United States v. Lot No. 50, 557 F. Supp. 72, 73-74 (D. Nev. 1982) (ex post facto clause applicable to forfeiture proceedings). In these cases, the courts did not rely upon a classification of forfeitures 
proceeding, therefore, should not automatically justify shifting the burden of proof to the claimant.

In Mathews v. Eldridge, ${ }^{67}$ the Supreme Court set forth a method for analyzing the constitutionahty of a challenged procedural rule. The Court said that to determine the specific dictates of due process a court must analyze three factors: first, the governmental interest served by the challenged procedure; second, the individual interest affected by the official action; and third, the risk of an erroneous deprivation and the probable value of additional procedural safeguards. ${ }^{68}$

Although Mathews involved an administrative denial of a statutory entitlement, ${ }^{69}$ the inethod developed in that case should apply in all cases to determine whether a procedural rule or practice coinports with the due process clause. ${ }^{70}$ The only recent case that has adhered to such analysis in a forfeiture proceeding is United States $v$. Veon. ${ }^{71}$ In Veon, the federal district court departed front the civil-criminal distimction for analyzing procedural due process requirements, and instead adopted the Mathews formula to rule on the validity of a court order restraining the transfer of property subject to an in rem forfeiture action. ${ }^{72}$ This note accepts the Veon court's use of Mathews, and hence, applies the Mathews test to determine whether burden shifting in forfeiture of drug proceeds actions comports with procedural due process guarantees.

\section{A. The Governmental Interest.}

The first part of the Mathews formula addresses the extent to which the challenged procedures advance legitimate governmental

as either civil or criminal proceedings; instead, they determined whether, for purposes of the particular constitutional guarantee, "criminal action" was defined to include forfeitures. See, e.g., Helvering v. Mitchell, 303 U.S. 391, 400 n.3 (1938); Zucker, 161 U.S. at 481-82.

67. 424 U.S. 319 (1976).

68. Id. at 335 .

69. Id. at 323-25.

70. Sce Lassiter v. Departınent of Social Serv., 452 U.S. 18, 27 (1981) (challenge to parentalrights termination proceedings).

In developing the formula, the Mathews Court inerely articulated the inethod of procedural due process analysis utilized in prior Supreme Court decisions. Mathews, 424 U.S. at 334-35. For exainple, in Fuentes, decided before Mathews, the Court einphasized the same three considerations. See Fuentes, 407 U.S. at 83 n.13, 84, 90 n.22, 91-92. The Mathews forinula has been subsequently applied in a variety of contexts. See, e.g., Santosky v. Kramer, 455 U.S. 745, 754 (1982) (burden of proof in parental-rights termination proceedings); Lassiter, 452 U.S. at 27 (right to counsel in parental-rights termination proceedings); Addington v. Texas, 441 U.S. 418, 425 (1979) (burden of proof in commitunent proceedings).

71. 538 F. Supp. 237 (E.D. Cal. 1982).

72. Id. at 247. 
objectives. ${ }^{73}$ Burden shifting allows the government to inake frequent use of the forfeiture device by easing the government's evidentiary burden. The forfeiture device itself promotes three important governmental interests. First, it generates and protects governmental revenues. ${ }^{74}$ Second, it punishes mdividuals who use their property to perpetrate criminal activity. ${ }^{75}$ Third, it regulates the unlawful use of property. ${ }^{76}$ Hence, by making forfeitures easier to carry out, burden shiftimg promotes these important governmental imterests.

Forfeitures generate governmental revenues through the sale of confiscated property and the capture of equipment and resources for governmental use. ${ }^{77}$ Forfeited items and their proceeds reimburse the government for both revenues lost by the proscribed conduct and expenses generated by enforcement of the prohibition. ${ }^{78}$ Using forfeitures to compensate for governmental costs created by the prohibited conduct is valid under the fifth amendinent's just compensation clause because they serve the remedial function of compensating the government with the offending property. ${ }^{79}$ Nevertheless, forfeiture of an imnocent party's property to support enforcement expenses would clearly violate the fifth amendment. ${ }^{80}$

Forfeitures serve as a punishment to the extent that they have the same practical effect as a fine. ${ }^{81}$ This is unobjectionable in criminal forfeitures because the government must establish the guilt of the of-

73. See Mitchell v. W.T. Grant Co., 416 U.S. 600, 607-08 (1974).

74. See Note, Forfeitures-Due Process-Supreme Court Upholds Forfeiture of Innocent Owner's Property Without Prior Notice and Hearing, 60 CoRnell L. Rev. 467, 478 (1975).

75. Boyd v. United States, 116 U.S. 616, 634 (1886); see United States v. Rush, 666 F.2d 10, 11 \& n.1 (2d Cir. 1981) (defendant who loaned money for purchase of illegal drugs held liable for criminal conspiracy and required to forfeit funds).

76. Calero-Toledo v. Pearson Yacht Leasing Co., 416 U.S. 663, 686-87 (1974). Senator Nunn, the sponsor of the bill amending the Drug Control Act to include the forfeiture of illegal drug proceeds, cited all three objectives as the purpose of the amendinent. 124 CONG. REC. 23,055 (1978).

77. See 21 U.S.C. $\$ 881$ (1982). The earliest coniparable analogy to the forfeiture device is the deodand. When an manimate object caused the accidental death of a man, the value of the object was forfeited to the King as a deodand so that it could be apphed toward the saying of masses for the good of the dead man's soul. See Calero-Toledo v. Pearson Yacht Leasing Co., 416 U.S. 663, 681 (1974). This device eventually turned into an inportant source of Crown revenue. Note, supra note 32, at 771 .

78. Helvering v. Mitchell, 303 U.S. 391, 401 (1938).

79. Compare id. at 49 with Kennedy v. Mendoza-Martinez, 372 U.S. 144, 168-69 (1963) and discussion infra notes 86-95 and accompanying text.

80. A forfeiture designed solely to produce revenue, without serving other governmental objectives, would violate the just compensation clause because it has the effect of placing the expense of public benefits on a few persons when it ought to be borne by all. See Arinstrong v. United States, 364 U.S. 40, 49 (1960).

81. See One 1958 Plymouth Sedan v. Pennsylvania, 380 U.S. 693, 700-01 (1965). The Court in 1958 Plymouth Sedan noted the potential harshness of the civil in rem forfeiture device: 
fending owner in a criminal proceeding with full procedural safeguards. ${ }^{82}$ Civil in rem forfeitures, however, should not be used as tools for imposing punitive sanctions for criminal violations because they do not utilize sufficiently protective procedures. Therefore, punishment is not a legitimate governmental interest in civil forfeitures. ${ }^{83}$ The government's regulatory objective in using forfeitures is to prevent criminals froin using property to commit a criminal offense. ${ }^{84}$ The government achieves this objective in a forfeiture proceeding by seizmg and condemning property that criminals used to perpetrate their crime. Forfeitures also deter the unlawful use of property and encourage persons who entrust property to others to ascertain the purpose for such a loan, lest the true owner forfeit his property when it is used in a crime. ${ }^{85}$ Reasonable regulation is an inherent and necessary part of any ordered society, ${ }^{86}$ and although regulations often limit an individual's enjoyment of his property, they do not constitute a "taking" that

If convicted of any one of the possible offenses involved, however, he would be subject, if a first offender, to a minimuin penalty of a $\$ 100$ fine and a maximuin penalty of a $\$ 500$ fine. In this forfeiture proceeding he was subject to the loss of his automobile, which at the time involved had an estimated value of approximately $\$ 1,000$, a higher amount than the maximum amount in the criminal proceeding.

Id. at 700-01 (footnotes omitted).

82. The Palmyra, 25 U.S. (12 Wheat.) 1, 14-15 (1827). During the Civil War, an exception developed to the general rule that forfeiture based on the criminal guilt of the owner required adjudication of his culpabihty in accordance with criminal law procedures. Congress authorized the in rem forfeiture of property located in the North owned by persons suspected of treason. Note, supra note 32, at 785. These acts prevented this property from being used to support the rebel army. Miller v. United States, 78 U.S. (11 Wall.) 268, 306 (1871). Congress adopted this hybrid approach because constitutional restrictions on criminal trials, such as the confrontation clause, made it impossible to obtain a conviction in most cases. Note, supra note 32, at 786 . At the same time, the normal approach to in rem forfeiture, focusing on the culpability of the property, was fruitless because it would not prevent the proscribed use in the first instance. In Miller, the Supreme Court had to rely on the war powers clause of the Constitution to uphold the validity of proceeding in an in rem forfeiture founded on criminal culpability. 78 U.S. at 305-06.

83. Punitive damages in a civil action can be distinguished from the use of forfeitures to punish criminal violations. A primary purpose of pumitive awards is to deter others froin engaging in grossly negligent or mtentionally tortious conduct. See e.g., Curtis Publishing Co. v. Butts, 351 F.2d 702, 717-18 (5th Cir. 1965), affd, 388 U.S. 130 (1967). The purpose, therefore, is not punishment per se, but the regulation of conduct through deterrence. In rem forfeitures, of course, can and do rely on the deterrent aspects of punishment to regulate the use of property. See infro notes 106-10 and accompanying text. When used solely to achieve retributive aims, however, civil in rem forfeitures undermine the structure of criminal law. $C$. United States v. Hall, 521 F.2d 406, 408 (9th Cir. 1975) (sentence conditioned on consent to forfeiture held in violation of Fed. $R$. Crim. P. 7(c)(2)).

84. Calero-Toledo v. Pearson Yacht Leasing Co., 416 U.S. 663, 687 (1974).

85. Id. at 687-88.

86. Cf. Pennsylvamia Coal Co. v. Mahon, 260 U.S. 393, 413 (1922) ("Government could hardly go on if to some extent values imcident to property could not be diminished without paying for every such charge."). 
requires just compensation. ${ }^{87}$ Indeed, the government's power to regulate can be broad enough, under the right circumstances, to deny an individual any use of his property. ${ }^{88}$

The constitutional limits on the government's use of the forfeiture device as a regulatory tool depend on the type of property to be forfeited and the relative innocence of the owner. Property legitimately subject to forfeiture falls into two categories. Per se contraband is property the inere possession of which constitutes a crime. ${ }^{89}$ Illicit drugs are an example. 90 The government has a strong interest in keeping inherently dangerous articles away from the pubhic. ${ }^{91}$ Even an innocent owner cannot compel the government to return such property..$^{92}$ Derivative contraband is property lawful to possess in the course of its normal use, ${ }^{93}$ which becomes subject to forfeiture when used as an instrument of crime. ${ }^{94}$ An automobile used as a getaway car is an example. In such cases, the government's right to confiscate derivative contraband extends no further than that which is necessary to prevent the property's unlawful use..$^{95}$

With derivative contraband, the relative innocence of the owner should determine the scope of the government's right to exercise forfeiture. An in rem forfeiture is undoubtedly proper when the owner knows of or consents to the property's unlawful use. ${ }^{96}$ Such a forfeiture may also be proper when the owner has failed to use reasonable care in

87. Cf. id. The Court in Pennsylvania Coal recognized, however, the difficulty in determining the point at which the state's regulatory power over property ends and the necessity for just compensation begins. Id. The line is a difficult one to draw because regulation of property reduces its economic value making the distinction partly one of degree. See Michelinan, Property, Utility and Fairness: Comments on the Ethical Foundations of "Just Compensation" Law, 80 HARv. L. REv. $1165,1190-93$ (1967). Courts and commentators developed various tools to meet this analytical problem, including the "invasion" theory, the "noxious use" test, the "diminution of value" theory, and the "government as enterprizer vs. government as mediator of values" test. See Sax, Takings and the Police Power, 74 YALE L.J. 36, 46, 48, 50, 62 (1964). Forfeitures, for the most part, would survive the constitutional line-drawing under any of these methods because they support the scheine of criminal law enforceinent.

88. See e.g., Mugler v. Kansas, 123 U.S. 623, 668-69 (1887) ("A prohibition simply upon the use of property for [certain] purposes . . . is only declaration by the State that its use . . is prejudicial of the public interests.").

89. One 1958 Plymouth Sedan v. Pennsylvania, 380 U.S. 693, 699 (1965).

90. Illegal drugs are subject to civil in rem forfeiture under the Drug Control Act. See 21 U.S.C. $\S 881(\mathrm{a})(1)(1982)$.

91. Cf. United States v. Jeffers, 342 U.S. 48, $53-54$ (1951) (Congress intended abrogation of property rights in contraband to prevent the spread of traffic in drugs).

92. See Trupiano v. Umited States, 334 U.S. 699, 710 (1948).

93. State v. Curran, 291 Or. 119, 628 P.2d 1198, 1203 (1981).

94. One 1958 Plymouth Sedan v. Pennsylvania, 380 U.S. 693, 699 (1965).

95. Calero-Toledo v. Pearson Yacht Leasing Co., 416 U.S. 663, 686-87 (1974).

96. See infra note 99-101 and accompanying text. 
determining whether the property is being used unlawfully. ${ }^{97}$ When the owner is otherwise innocent of wrongdoing, however, forfeiture may constitute an arbitrary taking of his property because the fact that another person used the owner's property to commit a crime does not necessarily make future unlawful use of the property likely. ${ }^{98}$

The Supreme Court has rejected the notion that the government can declare innocent owners' property forfeited. In Peisch v. Ware, ${ }^{99}$ decided in 1808, Chief Justice Marshall noted that forfeiture requires soine measure of fault by the property owner. ${ }^{100}$ If the owner cannot prevent the event giving rise to forfeiture, he cannot be deprived of his property. ${ }^{101}$ More recently, in Calero-Toledo v. Pearson Yacht Leasing Co., ${ }^{102}$ the Court stated that the Constitution forbids forfeiture when the owner has done all that reasonably could be expected to prevent the proscribed use. ${ }^{103}$ After Peisch v. Ware, the Supreme Court seems to have developed a general rule that deals harshly with the rights of innocent owners, ${ }^{104}$ suggesting that innocence can never serve as a defense to forfeiture. ${ }^{105}$ The Pearson Yacht Leasing decision, however, as

97. See infra notes 106-10 and accompanying text.

98. See infra notes $99-103$ and accompanying text.

99. 8 U.S. (4 Cranch) 347 (1808).

100. Id. at 363 .

101. For example, in Peisch v. Ware, customs officials sought to forfeit goods imported without bearing the appropriate marks and certificates. The Court overturned the forfeiture because the "importation" occurred when the vessel, shipwrecked in the Delaware Bay, was brought into port by sailors. Id. at $364-65$.

102. 416 U.S. 663 (1974).

103. Id. at 689. In United States v. One Ford Coach, 307 U.S. 219 (1932), a statute providing for the forfeiture of a vehicle used for transporting bottled liquor had an exculpatory clause covering the holder of a security interest who inquired as to the purchaser's reputation for bootlegging at the appropriate law enforcement office. Id at 221-22. The claimant credit company purchased the secnrity interest froin a local dealer. It inquired about the person executing the sales contract and secnrity agreenent, not knowing that the person's brother was the actual purchaser of the car. In ruling for the claimant, the Court interpreted the statute as requiring only a "reasonable inquiry." Id. at 236.

104. In J.W. Goldsmith-Grant Co. v. United States, 254 U.S. 505, 510 (1921), the Court criticized the harshness of forfeitures stating that if the issue had not been well settled, it probably would have limited this power to the property interest of the criminal offender.

105. Calero-Toledo v. Pearson Yacht Leasing Co., 416 U.S. 663, 680 (1974); Van Oster v. Kansas, 272 U.S. 465, 467 (1926); United States v. One Ford Coupe, 272 U.S. 321, 325 (1926); General Motors Acceptance Corp. v. United States, 286 U.S. 49, 57 (1923); J.W. GoldsmithGrant Co. v. United States, 254 U.S. 505, 510 (1921); Dobbin's Distillery v. United States, 96 U.S. 395, 401 (1877); United States v. Brig Malek Adhel, 43 U.S. (2 How.) 210, 234 (1844); The Palmyra, 25 U.S. (12 Wheat.) 1, 12-15 (1827).

The Court often avoided striking down overly harsh forfeiture statutes ou constitutional grounds by interpreting implied limitations. See, e.g., United States v. One Ford Coach, 307 U.S. 219, 236 (1939); Peisch v. Ware, 8 U.S. (4 Cranch) 347, 363 (1808). In United States v. Brig Malek Adhel, 43 U.S. (2 How.) 210 (1844), a case involving an act of piratical aggression by the crew, the Supreme Court upheld forfeiture of the innocent owner's vessel but overturned forfeiture of his 
the most recent Supreme Court statement on civil forfeitures, effectively disproves the existence of a blanket rule.

In those cases upholding harsh applications of the forfeiture device, circumstances existed that justified imposing vicarious liability on the seemingly innocent owners for the acts of others using his property. ${ }^{106}$ Historically, vicarious imposition of penalties occurred under customs and trade law because a shipowner was hable for the acts of his crew. ${ }^{107}$ In later analogous situations, courts held a landlord liable for a tenant's use of his property, ${ }^{108}$ and the holder of a purchase inoney security interest hable for his principal's use of the collateral. ${ }^{109}$ The rationale justifying such vicarious imposition of penalties is that it encourages care in the selection of those persons entrusted with property by imposing a duty of inquiry and imvestigation on the owner. ${ }^{110}$

Generally, proceeds, ${ }^{111}$ such as cash, are a type of derivative contraband that cannnot be forfeited unless the owner knew of or consented to the unlawful use. Unlike many tools or mstruments used in a crime, proceeds almost never put the owner on notice that the property may be linked to a criminal act, ${ }^{12}$ or create a duty of inquiry. In Pearson Yacht Leasing, for example, a company located in Puerto Rico leased a seaworthy vessel. ${ }^{113}$ The danger that such a ship, leased close to Latim America, could be used to smuggle drugs is great enough to require that the company take care to prevent the ship's unlawful use. ${ }^{114}$ Proceeds, on the other hand, only act as a fungible quality of value. ${ }^{115}$ Because proceeds do not provide notice of a potential link to

cargo. Id. at 237. Because the cargo was not an instrument in the criminal act of aggression, its forfeiture would not have advanced regulatory aims, thereby creating a constitutional violation. See infra notes 84-88 and accoinpanying text.

106. See generally Note, supra note 32 , at $779-800$.

107. Id. at 774.

108. Dobbin's Distillery v. United States, 96 U.S. 395, 401 (1877).

109. J.W. Goldsmith-Grant Co. v. United States, 254 U.S. 505, 510 (1921).

110. Pearson Yacht Leasing, 416 U.S. at 688; J.W. Goldsmith-Grant, 254 U.S. at 510.

111. See supra note 20.

112. Cf. Miller v. United States, 78 (11 Wall.) 268, 321-22 (1870) (Field, J., dissenting) (property is subject to seizure in proceedings in rem when it provides evidence of its own condemnation).

113. 416 U.S. at 663.

114. See J.W. Goldsmith-Grant Co. v. United States, 254 U.S. 505, 510-11 (1921). The facts of Pearson Yacht Leasing suggest one of the best argunents for inposing vicarious liability. Arguably, an individual could establish such a leasing arrangennent to cater to needs of criminals who do not desire to expose their personal assets to liability. Making the lessor vicariously liable undermines the value of such an arrangennent.

115. The term "proceeds" can cover virtually every type and form of property, as long as it has value and is the fruit of an illegal drug transaction. See 21 U.S.C. $§ 881$ (a)(6) (1982). Hence, the forfeiture statute apphies not only to proceeds received directly as a result of a drug exchange, but 
an illegal drug exchange, forfeiture of such proceeds is improper unless the owner knew of their link to an illegal transaction.

Applying the general principles of regulatory forfeiture to the forfeiture of proceeds under the Drug Control Act would require guilty knowledge as a prerequisite to forfeiture of the proceeds of a crime. Creating a duty of inquiry in the context of proceeds would constitute unreasonable regulation because the duty would apply in literally every transaction involving an exchange of money or property, making compliance effectively impossible. ${ }^{116}$ In addition, imposing vicarious liability in such circumstances will not advance the government's objective of undermining the financial basis of drug trafficking because the drug trafficker rarely will indemnify the innocent party forfeiting the proceeds. ${ }^{117}$ Governmental interests would be better served by confiscating an amount equivalent to the proceeds froin the criminal offender. ${ }^{118}$ Moreover, imposing vicarious liability gives government officials a potent tool for the arbitrary exercise of power. The quantity of tainted property subject to forfeiture could reach enorinous proportions because all property exchanged for previously tainted property would constitute proceeds "traceable to" soine previous illegal transaction. ${ }^{119}$

The regulatory objective served by the forfeiture of proceeds- destroying the financial basis of drug trafficking - should limit the use of the forfeiture device to circuinstances in which the owner knows of or consents to its unlawful use. Hence, the government has a justifiable interest in shifting the burden of proof in proceeds actions only when it can better accomphish its revenue and regulatory goals because of the reduced evidentiary burden. ${ }^{120}$ The revenue goal is only appropriate,

also, to property received in exchange for such proceeds. See United States v. Lot No. 50, 557 F. Supp. 72, 74 (D. Nev. 1982) (forfeiture of real property acquired with proceeds of illegal act).

116. Cf. City of Jacksonville v. Papachristou, 405 U.S. 156, 165 (1972) (vagrancy statute condemning normally innocent conduct struck down as overbroad).

117. See e.g., United States v. Lot No. 50, 557 F. Supp. 72,73 (D. Nev. 1982). In Lot No. 50, the Court overturned the forfeiture, however, holding that the ex post facto clause applied to proceeds obtained before amendment of the Act. Id.

118. Cf. supra note 114.

119. See supra note 20. The "substantial connection" requirenent enunciated in United States v. $\$ 364,960.00$ could serve to limit the excessive growth of tainted property. See 661 F.2d 319, 323 (5th Cir. 1981). The substantial connection doctrine has its origin in the "facilitation" requirement for the forfeiture of vehicles. Under the facilitation doctrine, an automobile used merely to transport an individual to the scene of the crime is not subject to forfeiture. Platt v. United States, 163 F.2d 165, 166 (10th Cir. 1947). This can be contrasted with those situations in which the driver of the automobile "participated" in the unlawful act by, for example, serving as lookout, transporting contraband, or serving as the locus of an illegal exchange. See, e.g., United States v. One Dodgc Coupe, 43 F. Supp. 60, 62 (S.D.N.Y. 1942). See Note, supra note 74, at 470 n.18 (criticizing distinction).

120. The government's interest in shifting the burden extends to the need for cost-efficient procedures. Mathews v. Eldridge, 424 U.S. 319, 347 (1976). Emphasis on efficiency, however, can 
however, if the forfeiture compensates the government for illegal activity, and the regulatory goal is valid only if the owner is not innocent. Innocence turns on whether the owner of the property has guilty knowledge, while the question of whether burden shiftmg is proper turns on whether the imdividual's interest im not being subject to forfeiture without guilty knowledge requires the government to bear the burden of proof despite the legitimate governmental interest in easier forfeitures.

\section{B. Private Interests Affected by Forfeiture.}

The second part of the Mathews formula addresses the individual's interests affected by the challenged government action. Forfeitures deprive the property owner of all his property rights. ${ }^{121}$ The due proccss clause protects an owner's right to use his property as well as his title to it. ${ }^{122}$ The sanctity of the owner's right to maintain title to his property is at least as old as Magna Charta. In Fuentes v. Shevin, the Supreme Court firmly established constitutional protection of an individual's right to the use of his property. ${ }^{123}$ The Court struck down a Florida replevin statute because it did not provide for preseizure notice and a hearimg. ${ }^{124}$ The Court engaged in an extensive analysis of the competing considerations, and concluded that private property rights were strong enough to mandate sucl preseizure notice and a hearmg before

never reach so far as to effectively destroy an interest protccted by the due process clause. Stanley v. Illinois, 405 U.S. 645, 656 (1972). The costs of traditional trial and hearing procedures are ordinary expenses, and "cannot outweigh the constitutional right." Fuentes v. Shevin, 407 U.S. $67,90 \mathrm{n.22}$ (1972).

121. See 21 U.S.C. $\$ 881$ (a) (1982). Deprivation of use occurs with the initial seizure as well as after condemnation. The important governmental interests in preventing the destruction, concealment, or continued use of contraband, however, preclude the imposition of rigid pre-seizure procedural safeguards. See Pearson Yacht Leasing, 416 U.S. at 679 (prcseizure notice and hearing denied); United States v. Veon, 538 F. Supp. 237, 243 (E.D. Cal. 1982) (ex parte order restraining transfer of property upheld).

122. See Pennsylvania Coal Co. v. Mahon, 260 U.S. 393, 416 (1922); Sax, supra note 87, at 50.

123. 407 U.S. at 86; see also North Ga. Finishing, Inc. v. Di-Chen., 419 U.S. 601, 606 (1975).

Although in rem forfeitures are characterized as actions against property, the applicability of constitutional guarantees remains unaffected. See, e.g., Boyd v. United States, 116 U.S. 616, 637 (1886); see also supra note 66. In Shaffer $v$. Heitner, for example, the Supreme Court adoptcd the "minimum contacts" requirenent for the exercise of quasi in rem jurisdiction statimg, "in order to justify an exercise of jurisdiction in rem, the basis for jurisdiction must be sufficient to justify exercising "jurisdiction over the interests of persons in a thing." " 433 U.S. 186, 207 (1977). The designation "in rein" is merely a legal fiction which does not change the cssential nature of such proceedings from a suit to determine the rights of persons. Hence, the Court in Boyd statcd, "Goods, as goods, cannot offend, forfeit, unlade, pay duties, or the like, but nicn whose goods they are." 116 U.S. at 637.

124. 407 U.S. at $96-97$. 
a creditor could replevy secured property. ${ }^{125}$ In Fuentes, the plaintiff in the default action had a security interest in the owner's property. ${ }^{126}$ The Court required a hearing to ensure that the secured party could not deprive the debtor of the property held as collateral without first inaking some type of factual showing that default was likely. ${ }^{127}$

The property interests of a claimant in a forfeiture action, however, are even greater than those of an owner of property subject to outstanding liens. In the analogous situation in which the government seeks to have forfeited the proceeds of a drug transaction, the Drug Control Act permits the government to deprive a person of his property without even the minimal evidentiary showing that the owner is not innocent. ${ }^{128}$ Yet, the government has no independent interest in the property apart froin its general drug enforceinent effort, ${ }^{129}$ and therefore, has weak justification for deprivation in the absence of proof of liability. ${ }^{130}$

Therefore, although the individual lias no right to use his property to support drug trafficking, he does have an interest in procedures that require the government to establish this relationship as a prerequisite to forfeiture. ${ }^{131}$ Forfeiture is improper if the claimant is an innocent owner of proceeds. If the shifting of the burden of proof on the issue of guilty knowledge, whicl determines the culpability of the owner, makes the risk of error intolerably great on this issue, the third branch

125. See id. at 84-96. The Court believed that the private property owner's interests were strong enough to warrant setting aside the statute even though the deprivation was only temporary, the petitioner lacked full legal title, and release of the property could be obtained by posting bond. Id. at 84-86.

126. The holder of a security interest has an interest in preventing the further use and deterioration of the collateral upon default, as well as a share of the title. See id. at 100-01 (White, J., dissenting).

127. See id. at 73-74; see also Mitchell v. W.T. Grant Co., 416 U.S. 600, 608 (1974); North Ga. Finishing, Inc. v. Di-Chem., 419 U.S. 601, 607 (1975).

128. See supra notes $26-32$ and accompanying text.

129. Cf. United States v. 1960 Bags of Coffee, 12 U.S. (8 Crancl1) 398, 409 (1814) (Story, J., dissenting).

130. In Bramble v. Richardson, the court relicd on Pearson Yacht Leasing to dismiss summarily, in dicta, the imphications of Fuentes for the validity of shifting the burden of proof in a forfeiture proceeding. See 498 F.2d 968, 973 (10th Cir. 1977). In Pearson Yacht Leasing, the Court refused to adopt the gencral rule, established in Fuentes, that property cannot be seized without prior notice and hearing. 416 U.S. at 679 . In rejecting the specific holding of Fuentes, however, the Pearson Yacht Leasing Court relied on circumstances that Fuentes itself recognized would create an exception to the general rule, namely, the government's interest in preventing the destruction, removal or concealment of contraband. Id. at 678-80. The Pearson Yacht Leasing decision, therefore, did not reject the Fuentes analysis but instead applied it to a different situation. The vitality of Fuentes in the forfeiture context was recognized explicitly by the Court. See id. at 679 \& n. 14.

131. Cf. Addington v. Texas, 441 U.S. $418,432-33$ (1979). 
of the Mathews test commands that the burden be left with the govern-, ment to prove guilty knowledge.

\section{Risk of Erroneous Deprivation.}

The third part of the Mathews test addresses the risk of an erroneous deprivation under the questioned procedures. ${ }^{132}$ Whether this risk of error is acceptable depends on the type of facts to be discerned, ${ }^{133}$ the adequacy of existimg safeguards, ${ }^{134}$ and the benefit of additional procedural safeguards. ${ }^{135}$

The key factual determination im a proceeds forfeiture under the Drug Control Act is the extent of the owner's knowledge of the criminal use of his property. ${ }^{136}$ The factual inquiry im a forfeiture proceeding closely resembles that in a criminal proceeding. The court must find a criminal act, ${ }^{137}$ a connection between the proceeds and that crimmal act, ${ }^{138}$ and the owner inust possess a state of inimd sufficient to warrant hability.

Under the safeguards provided by the Drug Control Act, the government inust deinonstrate probable cause and the owner can bar forfeiture by disproving the elenents of the forfeiture action. The probable cause requirement reduces the potential for error somewhat, but only assures that a "reasonable suspicion" exists that the alleged facts are true. ${ }^{139}$ The courts never have considered probable cause sufficient proof of the "guilt" of the property.140 Instead, "preponderance of the evidence," rather than inere probable cause, is the historical standard of proof required for imposing a civil forfeiture. ${ }^{141}$ Consequently, the Drug Control Act's dimimished requirements for the government's prima facie case in a forfeiture break with tradition im a way that significantly increases the likelihood that property owners will forfeit confiscated property. ${ }^{142}$ An increase in the number of forfeiture

132. 424 U.S. at 335.

133. Id. at 343 .

134. Id. at $345-46$.

135. Id. at $346-47$.

136. See supra notes 110-19 and accompanying text.

137. See United States v. \$4,255,625.39, 551 F. Supp. 314, 323 (S.D. Fla. 1982).

138. United States v. One 1978 Chevrolet Impala, 614 F.2d 983, 985 (5th Cir. 1980).

139. See supra notes $30-32$ and accompanying text.

140. In Locke v. United States, Chief Justice Marshall stated that " 'probable cause' . . means less than evidence which would justify condemnation." 11 U.S. (7 Cranch) 339, 348 (1813). Marshall approved of shifting the burden of proof only because the reasonable suspicion justified demanding an explanation of the circumstances from the claimant. Id. at 346-47.

141. See United States v. Regan, 232 U.S. 37, 48 (1914).

142. In United States v. $\$ 4,255,625.39,551$ F. Supp. 314, 316-22 (S.D. Fla. 1982), a proceeds forfeiture case, the only evidence establishing probable cause were the large sums involved, the 
cases that the government wins seems likely to lead to more frequent erroneous deprivations of property. ${ }^{143}$

The primary justification for requiring only a probable cause showing by the government and shifting the burden is that the failure to produce exculpatory evidence provides circumstantial proof of liability. This reasoning assumes that an innocent claimant ought to be able to disprove the elements of forfeiture. ${ }^{144}$ Yet the claimant does not necessarily liave ready access to the facts supposedly linking the suspected property to an actual crime. Unless lie knew of or participated in the crimimal act, he is im no better position than the government to carry tlie burden of proof. ${ }^{145}$

Besides having to prove facts about which lie has little information, the claimant in a Drug Control Act forfeiture must prove that the allegations against him are not true. For purposes of the forfeiture the property owner is presumed guilty unless he can prove that he is innocent. Such an allocation of the burden of proof creates a greater risk of an erroneous deprivation than if the government were required to produce affirmative proof. The element of disproving knowledge presents a good example of the difficulty of proving a negative. The owner must stand in court and proclaim his lack of knowledge, yet there is rarely any hard evidence of this. On the other hand, if the government were to bear the burden of proof, as it does in a criminal case, it usually could produce affirmative evidence that the claimant knew of the intended criminal use of his property. Sucli proof of a party's state of mind poses problems, to be sure; but the government routinely overcomes such problems in all criminal prosecutions except those involving strict liability offenses. No doubt the claimant still would have a substantial imcentive to make self-serving demials of what he knew, but the trier of fact can always dismiss the owner's claim of a lack of knowledge as an untrustworthy statement to save his property. Indeed, it is probable that the trier of fact is likely to disregard as untrustwortlyy an owner's denial of implicating knowledge, regardless of which party carries the burden of proof. If the trier of fact does disregard sucli testimony, and the government is not required to make any independent showing of implicating knowledge of a crime, the government will win

fact that the events occurred im Miami, and the fact that the money was deposited im a bank account maimtamed by an affiliate of a Colombian corporation.

143. Of course, the property owner is also protected by being able to disprove the facts that the government alleges.

144. See, e.g., Locke v. United States, 11 U.S. (7 Cranch) 339, 346-47 (1813).

145. In Pearson Yacht Leasing, for example, the lessor did not even learn that the vessel had been seized until it sought repossession after it failed to receive rent from the lessee. 416 U.S. at 668. 
most forfeiture cases. If the government wins more forfeiture proceedings in cases in which the claimant is actually guilty of the offense which the statute proscribes, then the risk of erroneous deprivation of property is minimal and the due process concerns are lessened. But, in the typical forfeiture case involving a truly innocent property owner, that owner usually will have to rely primarily, if not solely, on his own testimony. ${ }^{146}$ If the innocent owner has the misfortune to possess a suspicious demeanor, the trier of fact may disbeheve his self-serving testimony. ${ }^{147}$ Because the presumptions are reversed, the owner will then lose his property based solely upon the government's showing of probable cause. In many cases, the same suspicious circumstances that serve as the basis for disregarding the claimant's testimony also will have given rise to the finding of probable cause with the result that establishing probable cause makes forfeiture a fait accomph. 148 If the procedures cause innocent property owners to forfeit their property, then the risk of erroneous deprivation of property is increased and the due process test set forth in Mathews possibly is violated. ${ }^{149}$

\section{An Alternative Division of Burdens of Proof in Drug Proceeds Forfeitures.}

Because the Drug Control Act's shift in the burden of proof appears to establish an undue risk of error, an alternative allocation of the

146. See, e.g., United States v. $\$ 2500,689$ F.2d 10, 12 (2d Cir. 1982), cert. denied, 104 S. Ct. 1591 (1984).

147. The trier of fact can choose to disbelieve a witness even if his testimony is uncontradicted and unrefuted. Sartor v. Arkansas Natural Gas Corp., 321 U.S. 620, 627-28 (1944).

148. In United States $v$. $\$ 2500$, the district court disregarded testiniony by the claimant's wife and mother that the seized money represented wages earned by him and cash belonging to his mother. 689 F.2d 10, 11-12 (2d Cir. 1982).

The claimant's testimony is even less valuable when the property's relationship to the criminal act is undisputed, and only the knowledge of the claimant is in doubt. Although the owner's testimony is generally the only evidence directly probative of knowledge, the trier of fact is unhikely to be persuaded by sueh self-serving evidence.

149. See supra notes $140-41$ and accompanying text. The existence of admistrative remittance procedures does not sufficiently protect the owner froin a wrongful deprivation. Remittance procedures provide for possible return of forfeited property upon petition for approval by the Attorney General. United States v. One 1976 Porsche 911S, 670 F.2d 810, 813 (9th Cir. 1979); 19 U.S.C. $\S 1618$ (1982); 21 U.S.C. $§ 881$ (d) (1982). Remittance is not available as a matter of right, but depends solely on the unreviewable discretion of the government official handling the petition. Umited States v. One 1973 Buick Riviera, 560 F.2d 897, 900 (8th Cir. 1977); see also United States v. One 1972 Toyota Mark II, 505 F.2d 1162, 1165 (8th Cir. 1974) ("The Attorney General has exclusive authority to rennit or mitigate forfeitures;" trial court has no authority to review decision). In this respect, the discretionary nature of remittance procedures makes them ineffective for protecting agamst wrongful deprivation because they are designed to grant leniency in light of countervailing circumstances, not to review the validity of the origimal judgment. See United States v. One Clipper Bow Ketch Nisku, 548 F.2d 8, 11 (1st Cir. 1977). 
burden of proof should be considered in order to better satisfy the $\mathrm{Ma}$ thews formula. ${ }^{150}$ The best allocation of the burden maximizes protection for the imdividual against an erroneous deprivation, but minimizes obstacles to efficient and effective drug law enforcement by the government. ${ }^{151}$

The approach recommended in this note is a tripartite division of the burden of proof. ${ }^{152}$ First, the government maintains its initial burden of showing probable cause. Second, the burden then shifts to the claimant to articulate a reasonable explanation rebutting probable cause. Finally, the government bears the ultimate burden of proving either the elements of a forfeiture or that the owner's proferred explanation was a pretext.

The first stage of the burden, establishing probable cause, is identical to current practice. ${ }^{153}$ Maimtaining the probable cause showing spares the government the expense of proving liability in cases in which the owner declines to defend the action. The owner is likely to decline if he is guilty of the criminal offense, and, by challenging forfeiture, would risk subsequent crimmal prosecution, ${ }^{154}$ or if the available evidence clearly establishes the validity of forfeiture. ${ }^{155}$

The second stage requires the claimant to articulate a reasonable explanation rebutting probable cause. In this step, the claimant must state facts which, if true, would either undermine the factual predicate

150. See, e.g., Santosky v. Kramer, 455 U.S. 745, 769 (1982) (clear and convincing evidence required to terminate parental rights).

151. The ideal division, however, would not necessarily be the only constitutionally sustainable assignment of the burden of proof. The government could, of course, assign itself a more stringent burden than that needed to protect the interests of the individual.

152. This approach is similar to that developed by the Supreme Court for Title VII actions for intentional employment discrimination: First, the plaintiff must establish a prina facie case of discrinination; second, the defendant inust articulate a legitinate, nondiscriminatory reason for the challenged action; third, the plaintiff inust then prove that the proferred explanation was only a pretext hiding imtentional discrinination. McDonnell Douglas Corp. v. Green, 411 U.S. 792, 802-04 (1973).

153. The first stage is the major difference between the procedure recoininended here and Title VII actions. Rather than requiring a priina facie case, the recoininended procedure dennands only a showing of probable cause. The lower burden allows the government to begin proceedings against property under highly suspicious circunstances where it would be unable to produce, at this prehminary stage, evidence of each of the eleinents of a forfeiture. Compare McDonnell Douglas Corp. v. Green, 41 I U.S. 792, 802 (1973) with supra notes 30-32, 140 and accompanying text.

154. See United States v. Hall, 521 F.2d 406, 407 (9th Cir. 1975) (one-year sentence suspended upon consent to forfeiture of offending property).

155. See, e.g., Lee v. Thornton, 398 F. Supp. 970, $973-75$ (D. Vt. 1975). 
of probable cause or establislı that the property is not subject to forfeiture. ${ }^{156}$ The claimant would not have to prove his allegations, ${ }^{157}$ however, thus eliminating the effect of built-in suspicion of his testinnony or his inability to prove his innocence. He would, however, have to coinmit himself to a particular version of the facts, and thus narrow the scope of the government's investigation and provide the governinent with the information it needs to construct its affirmative case. ${ }^{158}$

Courts can develop judicial standards for determining when the owner's allegations are specific enough to rebut probable cause. Because of the variety of bases upon which the forfeiture of proceeds can be defended, to develop a list of facts that would satisfy the claimant's burden is impossible. ${ }^{159}$ A flexible standard, similar to that now governing probable cause, ${ }^{160}$ would be best.

In the third stage, the government must prove, by a preponderance of the evidence, either the three elements of a forfeiture or at least that the property owner's proferred explanation was a pretext. ${ }^{161}$ This stage places the ultimate burden of proof on the government, ${ }^{162}$ and protects the individual from an arbitrary deprivation of his property.

156. Cf. Texas Dep't of Community Affairs v. Burdine, 450 U.S. 249, 253 (1981) (plaintiff carries ultimate burden under Title VII).

The fifth amendment's provisions against self-incrimination raise serious questions about the constitutionality of requiring a claimant to produce a reasonable explanation, under both the existing procedure with its shifted burden and the recommended procedure. In Griffin v. California, 380 U.S. 609, 613 (1965), the Supreme Court held that guilt could not be imferred from the exercise of the right to remain silent. Forcing the claimant to choose between asserting a defense and assenting to forfeiture violates this principle. In United States v. United States Coin \& Currency, 401 U.S. 715, 717-18 (1971), the Court firnly established the applicability of the self-incrimination clause to forfeiture proceedings. Resolution of the issue would appear to require either a flexible interpretation of the self-incrimination clause, an overruling of United States Coin \& Currency, or placing the full burden of proof on the government at the outset.

157. See supra notes 28-29 and accompanying text.

158. See Texas Dep't of Community Affairs v. Burdine, 450 U.S. 249, 258 (1981).

159. In a Title VII action this presents fewer problems because the initial stage-demonstrating a prima facie case-has fairly clear guidelines which have been developed over time and provide more direction concerning the facts needed to rebut the prima facie showing. See, e.g., McDonnell Douglas Corp. v. Green, 411 U.S. 792, 802 (1973). In most Title VII actions, rebuttal will require an explanation of, for example, the hiring standards utilized and the speciflc reasons why the plaintiff did not meet them. See Texas Dep't of Community Affairs v. Burdine, 405 U.S. 249 , 254-55 (1981).

160. See generally Illinois v. Gates, 103 S. Ct. 2317, 2328 (I983) (Court discarded two-part test for determinimg the reliability of an infornant's infornation in establishing probable cause for search warrants in favor of a "totality of the circumstances" test).

161. For example, suppose the claimant alleges he does not know the individual who used his property unlawfully. Proof that the two were prior acquaintances would disprove the explanation and satisfy the government's burden.

162. See Texas Dep't of Community Affairs v. Burdine, 450 U.S. 249, 253 (1981). 


\section{Conclusion}

In a proceeds forfeiture action, the due process clause requires a delicate balancing of governmental and individual interests. The government's interest in the proceeds of an illegal drug excliange extends only to property used with the knowledge or consent of the owner. Due process compels procedures that limit the risk of erroneous deprivation of property. The tripartite division of proof that this note proposes achieves this goal without unduly hindering valid governmental objectives. First, requiring the government to show probable cause prevents the arbitrary institution of forfeiture suits. Second, requiring the claimant to articulate a reasonable explanation commits him to a particular version of the facts without placing the risk of evidentiary insufficiency upon limi. Finally, requiring the government either to prove liability or to disprove the proferred explanation places the burden of proof on the party best able to carry it, so that the risk of an erroneous determination is reduced to a reasonable level. 
- 